\title{
Why do elderly men desire youth instead of aging? An analysis of Kangnoseonsaeng-Jeon (却老先生傳) by Lee Ok (李鈺)
}

\section{Kun Hwang}

Ethics Editor, Archives of Plastic Surgery

Department of Plastic Surgery, Inha University College of Medicine, Incheon, Korea

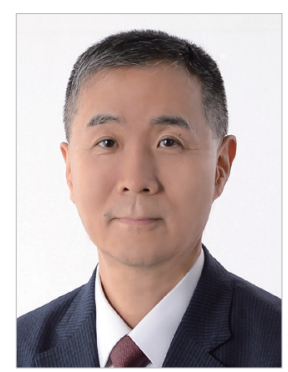

"In the morning, my hair was black like silk bundles. In the evening, it became white like snow (朝如青絲暮成雪).”-Li Bai (李白, 701-762 AD, a Chinese poet)

With the snapping of smartphone cameras, photographs are everywhere these days. In our visual society, everybody's insecurities are stamped in time in the annals of the internet. Therefore, troublesome physical features prompt both men and women to undergo plastic surgery.

Recently I read a book written in Korea 200 years ago (during the Joseon period). The writer, Lee Ok (李鈺, 1760-1815), wrote Kangnoseonsaeng-Jeon (却老先生傳, Chronicle of Mr. Tweezer) at the age of 50. This book personifies a tweezer as a narrator, and is structured as a set of questions and answers that express psychological anxiety about aging. The author was sensitively aware of aging and described the aging process of the body in detail. The descriptions of changes in hair color and locations are especially impressive [1]. The author would like to delay aging - if not the aging process itself, then at least aging of one's external appearance-by plucking out gray hairs (Fig. 1).

In this book, the following reasons for plucking out gray hairs are given: (1) in order to serve in a governmental post, men must avoid looking old; (2) if one's parents are still alive, their son should not look older than his parents; (3) if a man marries a young wife, the husband's old appearance must be avoided; or (4) society treats elderly men poorly.

From this book, we realize that 200 years ago in Korea, aristocrats (兩班) desired to look young for reasons related to their jobs, social treatment, and marital relationships, just as is the case now. The only difference relates to filial duty, as a good son was expected to avoid looking older than his parents.

It is notable that the author wrote, "It is not sad to die, but it is sad to grow old. People hate aging because they are getting closer to death," which expresses a remarkably modern sentiment, but was written 200 years ago.

In our times, elderly men dye their gray hair rather than plucking it out. Cosmetic surgery for men is becoming increasingly common throughout the world. If the author lived in Seoul today, he might have written the "Chronicle of Mr. \#15 Blade" instead of the "Chronicle of Mr. Tweezer."

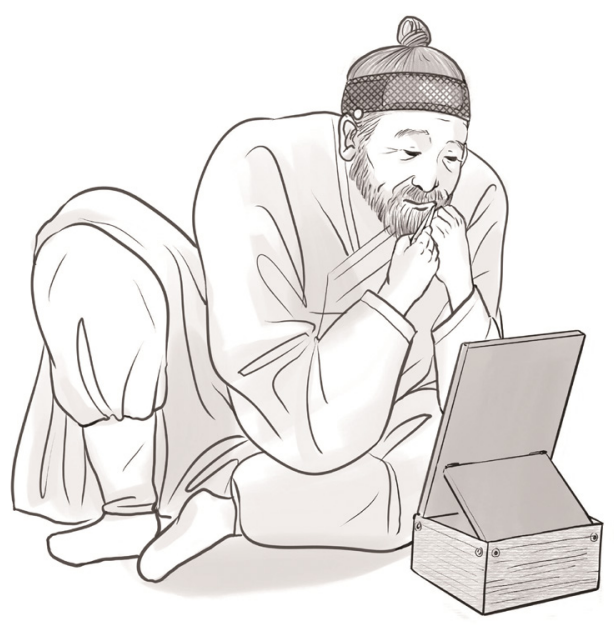

Fig. 1. An old writer is tweezing gray hairs. Illustration by Hye Won Hu, MFA, Division of Biomedical Art, Incheon Catholic University Graduate School (Incheon, Korea). 


\section{NOTES}

\section{Conflict of interest}

Kun Hwang is an editorial board member of the journal but was not involved in the peer reviewer selection, evaluation, or decision process of this article. No other potential conflicts of interest relevant to this article were reported.

\section{ORCID}

Kun Hwang https://orcid.org/0000-0002-1994-2538

\section{REFERENCE}

1. Ahn SH. A study on Kangnoseonsaeng-Jeon of Lee Ok: focusing on the aging and autobiography. J Korean Literature Chin 2016;45:253-76.

Correspondence: Kun Hwang

Department of Plastic Surgery, Inha University College of Medicine, 27 Inhang-ro, Jung-gu, Incheon 22332, Korea

Tel: +82-32-890-3514, Fax: +82-32-890-2918, E-mail: jokerhg@inha.ac.kr

This study was supported by a grant from National Research Foundation of Korea (NRF-2020R1/1A2054761).

Received: August 5, $2021 \bullet$ Revised: August 22, 2021 • Accepted: August 23, 2021 pISSN: 2234-6163・ elSSN: 2234-6171

https://doi.org/10.5999/aps.2021.01578• Arch Plast Surg 2021;48:575-576 